\title{
Invited review: Cessation of lactation: Effects on animal welfare
}

\author{
G. Zobel, ${ }^{* 1}$ D. M. Weary, ${ }^{*}$ K. E. Leslie,† and M. A. G. von Keyserlingk ${ }^{* 2}$ \\ *Animal Welfare Program, Faculty of Land and Food Systems, University of British Columbia, 2357 Main Mall, Vancouver, British Columbia, \\ V6T 1Z4, Canada \\ †Department of Population Medicine, University of Guelph, Stewart Building, Guelph, ON, N1G 2W1, Canada
}

\begin{abstract}
The forced cessation of milk production, or dry-off, is a routine management practice in dairy cattle, sheep, and goats. This practice initiates a dry period, during which the animal is not milked. Milking begins again after parturition. Most of the literature on the dry period has focused on how various drying-off strategies affect milk production and disease; little work to date has addressed how dry-off affects the overall welfare of the dairy animal. The first aim of this review was to present an overview of the importance of dry-off and how it is commonly achieved. Our review shows that much scientific progress has been made in improving health status between lactations. The second aim was to identify important gaps in the literature, of which 2 key research disparities have been identified. We find that much of the work to date has focused on cattle and very little research has examined dry-off in dairy sheep and goats. We also find a lack of research addressing how common dry-off methodologies affect animal welfare on more than just a biological level, regardless of species.
\end{abstract}

Key words: natural behavior, dry-off, intramammary infection, dairy cow, dairy goat

\section{INTRODUCTION}

Female ruminants, including cows, ewes, and does, initiate lactation immediately following birth. Under natural conditions, offspring will be nursed for 5 to 12 mo, depending on the species. Milk production increases rapidly, peaks, and then slowly declines until the offspring become nutritionally independent. At this point, milk production ceases, and the birth of the next offspring begins the cycle again. Conversely, in most commercial dairy systems, the offspring are separated

\footnotetext{
Received March 23, 2015.

Accepted August 8, 2015.

${ }^{1}$ Current address: AgResearch Limited, 10 Bisley Street, Private Bag 3123, Hamilton, New Zealand.

${ }^{2}$ Corresponding author: nina@mail.ubc.ca
}

from the mother within hours of birth, and milk is redirected for collection and human consumption. The resulting lactation cycle is different from what would occur in a natural setting. Dams are encouraged to produce large amounts of milk, and eventually milk production is abruptly ceased for a short period before the birth of new offspring.

The benefit of a rest from lactation, or dry period, has been acknowledged since the early 1800s (reviewed by Dix Arnold and Becker, 1936) in dairy cows. A dry period is now standard on most dairy farms. In the case of the cow, most farmers aim for one calf per cow per year, allowing for approximately $305 \mathrm{~d}$ of lactation and $60 \mathrm{~d}$ when it is not lactating (dry). Much research has focused on the physiological effects of the dry period. Progress has been made in understanding mammary physiology at the cellular level (e.g., Wilde et al., 1999) and how this ties into milk production during the next lactation (e.g., Bachman and Schairer, 2003). Also, the effects of dry period management on IMI have received a great deal of attention (e.g., Dufour et al., 2011). Even though knowledge of dry period mammary health has expanded, our knowledge of how the individual animal is affected by the way we manage the dry period remains minimal.

Few working in the dairy industry today would disagree with the fact that poor health and reproduction are bad for the animal and farm profitability. Nonetheless, a health-only focus is not sufficient. Concerns regarding animal welfare go beyond health, with proponents arguing that assurances for good welfare are only achieved when 3 key components are balanced: (1) the biological functioning (including health) of the animal, (2) the affective states the animal is experiencing, and (3) the naturalness of its life (Fraser et al., 1997). It follows that when seeking to understand how welfare is affected by cessation of lactation, it is vital to identify how the associated management practices affect productivity and health, prevent states such as pain and hunger, and affect the natural adaptations of the animal.

The first part of this review summarizes the abundance of research related to dry-off and the dry period 
that has focused on milk production, metabolic status, and udder health (i.e., IMI). Next, an argument is presented that this narrow focus on biological functioning has ignored how dairy animals actually experience the cessation of milking (e.g., Do they experience pain when milking is stopped?). Last, a brief overview is given of how standard management practices used in today's dairy industry have resulted in a lactation cycle that strongly deviates from a natural one. Exploring this deviation and how it affects dairy animals could provide insight into finding solutions for welfare concerns facing the dairy industry. Given the available literature, the majority of this review focuses on the dairy cow. Where applicable, evidence from other mammalian species, in particular dairy sheep and dairy goats, is discussed.

\section{BIOLOGICAL FUNCTIONING AND HEALTH}

\section{Mammary Involution and Apoptosis}

A major area of focus within the dry-off literature is that of cellular processes occurring at dry-off. Mammary involution, or the process where a gland moves from a lactating state to a nonlactating state, occurs in all lactating mammals and can be categorized into 3 main types: gradual, senile, and acute involution.

Gradual involution occurs early in lactation and results in the slow decline of milk production observed in the natural lactation cycle (Wilde et al., 1999). The point at which gradual involution occurs is dependent on peak milk yield and is therefore highly species specific (e.g., rats, 12 d: DeSantiago et al., 1998; humans, 40 d: Butte et al., 2002; cows, 45 to 90 d: Stanton et al., 1992; Khorshidie et al., 2012; sheep, 35 to 40 d: Pollott and Gootwine, 2000; Ruiz et al., 2000; goats, 50 to 124 d: Gipson and Grossman, 1990) and is also variable by breed within species.

Senile involution refers to an age-related decline in the mammary gland's ability to produce milk. The high culling rate (or turnover rate of individual animals within a herd) frequently observed in many intensive commercial milk production systems (Oltenacu and Algers, 2005) has resulted in a reduced average age at removal from the herd; thus, this aspect of involution has received little focus within the dairy science literature. Senile involution is largely only considered in human literature (Neville, 1983; Silanikove, 2014).

Acute involution occurs when milk removal from the mammary gland is ceased. This can occur naturally (e.g., death of an offspring) or, as is common in the modern dairy industry, when lactation is abruptly halted in preparation for the dry period before the birth of the offspring. When milking is ceased abruptly, the cisternal ducts and alveoli of the udder become engorged, rais- ing intramammary pressure (Oliver and Sordillo, 1989). This local physical change triggers the involution process (Wilde et al., 1997). Rodent work has shown that apoptosis, or programmed cell death, has a negative relationship with the presence of galactopoietic hormones (i.e., hormones that stimulate milk production; e.g., prolactin; Wilde et al., 1997). When milk is no longer removed from the gland, prolactin production ceases, triggering apoptosis. Apoptosis occurs with all 3 types of involution, but the highest rate of apoptosis is associated with acute involution. A major difference between apoptosis and trauma-related cell death (i.e., necrosis) is that the former does not elicit an immune response, thus generating no inflammatory response. Because no inflammation is triggered by apoptosis itself (Wilde et al., 1997), it has been suggested that any inflammation that does occur is therefore a result of excessive milk engorgement caused by acute involution. Hence, monitoring for an inflammatory response could be a useful indicator of any tissue damage caused by abrupt cessation of milking, which is pertinent because this practice has been receiving increasing criticism (e.g., Bertulat et al., 2013). This hypothesis is supported by work showing that although mammary glands with low engorgement do exhibit some inflammatory response (likely due to a backlog of clearing of dead cells), the cell types involved in the inflammatory response are different when engorgement is high (Silanikove et al., 2013). This difference led the authors to conclude that abrupt mammary involution associated with sudden cessation of milking causes distress in high-producing cows.

The level of net cell death due to apoptosis of milk epithelial cells (MEC), and regression of surrounding mammary tissue, is species dependent. Rodents appear to have the most significant losses of MEC (Paape and Tucker, 1969) and collapse of alveoli (Li et al., 1999). Conversely, much less tissue degeneration occurs in cows (Capuco et al., 1997), sheep (Tatarczuch et al., 1997), and goats (Sordillo et al., 1984). It has been shown that the alveoli decrease in size corresponding to the reduced milk secretory activities within them, but the surrounding stromal (i.e., connective) cells increase in size, resulting in many of the alveoli staying intact (cows: Li et al., 1999; sheep: Tatarczuch et al., 1997). Although a rudimentary indicator of potential changes in alveoli structure in dairy goats, it has been noted that lactating and nonlactating glands on the same animal remained similar in size (Fowler et al., 1991).

It follows that with species contrasts (e.g., between cows, sheep, and goats) in tissue degeneration and apoptosis during involution, the necessity of the dry period across species would also be questioned. Omitting the dry period entirely does not result in a net loss 
of MEC (Capuco et al., 1997), suggesting that milk production should not be negatively affected if cows are not dried off. However, as outlined by a review by Bachman and Schairer (2003), milk production is clearly reduced in the next lactation when dairy cows are not provided a dry period. Involution is believed to promote the removal of senescent (i.e., older, nondividing) cells and the production of new MEC (Capuco et al., 1997). Because MEC must differentiate to develop lactational capacity, the level of differentiation is indicative of cell age. The level of cell turnover can be estimated by the presence (or absence) of highly differentiated cells; cell turnover is highest when various stages of differentiation are observed. Older MEC are known to have decreased milk secretory abilities because of their tendency toward dedifferentiation as they age (Wilde et al., 1997; Capuco and Akers, 1999). Therefore, it would appear that promoting the turnover of MEC, thus ensuring that MEC differentiate near parturition, would be advantageous for optimal milk production in the new lactation. This hypothesis works well for explaining the importance of involution in cows and sheep, but the evidence is less clear for goats.

In one goat study, although an omitted dry period decreased cell turnover, the increased number of differentiated MEC did not appear to correspond to a decrease in milk production in the next lactation (Safayi et al., 2010). Indeed, of the 3 studies examining the omission of a dry period in dairy goats (Fowler et al., 1991; Caja et al., 2006; Safayi et al., 2010), only Caja et al. (2006) suggested that milk production was negatively affected. Unfortunately, because of goats spontaneously drying up, the sample sizes were small and uneven between study groups, making it difficult to draw substantive conclusions. Furthermore, neither this nor the other 2 aforementioned studies controlled for peak milk production, production persistence, and number of kids, all of which are known to influence next-lactation milk production (Gipson and Grossman, 1990; León et al., 2012). So from existing work, it is not possible to conclude whether increased number of differentiated MEC (indicating low cell turnover) actually corresponds to a decrease in milk production in goats, as observed in cows. Goats may simply have longer MEC survivability compared with cows, allowing older MEC to sustain milk production for longer. More studies are needed to determine the difference in MEC proliferation rates between the species.

\section{Dry Period Length and Omission: Effect on Milk Production}

Complementing the cellular level research that suggests omitting a dry period is not advantageous in terms of milk production in cows, another large body of literature has focused on understanding the ideal dry period length. Early retrospective reviews of milk production records suggested that dry periods of 30 $\mathrm{d}$ or less had negative effects on milk production in subsequent lactations of dairy cows (e.g., Klein and Woodward, 1942; Wilton et al., 1967). However, with the potential financial gains of shorter dry periods (e.g., Santschi et al., 2011b) being considered, research in this area has continued, collectively demonstrating the complexity of choosing the correct dry period length. For instance, 30-d dry periods were successfully implemented without affecting milk production in several controlled trials (e.g., Bachman, 2002; Gulay et al., 2003), whereas others have shown the opposite effect (Bernier-Dodier et al., 2011; Steeneveld et al., 2013). Furthermore, it has been suggested that short dry periods (e.g., 28 d: Pezeshki et al., 2007; 35 d: Santschi et al., 2011a) appear to only negatively affect the milk yield of primiparous cows, and if the dry period is extended slightly (40 to 45 d: Kuhn et al., 2006), these effects could be negated. It has also been suggested that the negative milk production effects of short dry periods (e.g., less than $45 \mathrm{~d}$ ) may be breed dependent, with Brown Swiss faring better than Holsteins in terms of maintaining milk production in the next lactation (El-Tarabany, 2015).

In goats, dry period length can be considered a function of lactational persistence (Knight and Wilde, 1988; Caja et al., 2006). Persistence can be partially explained by how MEC numbers are regulated throughout lactation. Although the number of MEC decline after peak lactation, these cells stay highly differentiated toward secretory activity in goats (Wilde et al., 1997). Thereby, lactation is continued, even in animals that are pregnant (Knight and Wilde, 1988). Yet, it is not clear why some animals are more persistent than others. In a half-udder experiment where one gland was dried off 9 wk before parturition and the other gland was continuously milked, Safayi et al. (2010) found that only 6 out of the 13 glands that were kept milking actually continued producing milk until parturition. However, because this was a half-udder study, it is difficult to differentiate between true persistence and the potential effect decreased galactopoietic hormone levels, initiated by the dry gland, might have had on the lactating gland. Caja et al. (2006) aimed to compare continuously milked goats to those on a 56-d dry period. Of the 8 goats assigned to the continuous milking group, only 3 goats continued lactating through to kidding. However, it should be noted that those that dried up spontaneously (and therefore had a shortened dry period between 23 and $31 \mathrm{~d}$ ) had no difference in milk production compared with goats with the 56-d dry 
period. In sheep, a large-scale retrospective study has demonstrated that dry periods shorter than $30 \mathrm{~d}$ are detrimental to milk production in the next lactation (Hernandez et al., 2012). However, controlled work is required to disentangle the effects of dry period length from the variability in management practices common in a commercial setting.

\section{Dry Period Length and Omission: Effect on Negative Energy Balance}

The complexity of achieving an ideal dry period length is furthered by its contradictory effect on milk production and metabolic status. Negative energy balance is a common occurrence after parturition in cows because of the metabolic demands of milk production (Butler and Smith, 1989). In goats and sheep, the condition more frequently occurs before parturition as a consequence of the growing fetal energy requirements (Marteniuk and Herdt, 1988; Edmondson and Pugh, 2004). Many animals are able to cope by metabolizing body fat reserves into NEFA and glycerol; yet, if too much of this occurs, hepatic lipidosis can result as the liver becomes overwhelmed with NEFA (Van Saun, 2000; Mulligan and Doherty, 2008). The outcome is typically an excessive release of ketone bodies (Harmeyer and Schlumbohm, 2006). When left untreated, the conditions (e.g., pregnancy toxemia before parturition, ketosis after parturition) can be fatal. Although the primary focus of the dry period in dairy animals has been to achieve the best possible milk production and udder health in the next lactation, research in cows has also considered the effects of the dry period on metabolic status.

Shortened and skipped dry periods shift a portion of the milk production to the prepartum period and reduce milk production in the next lactation (Bachman and Schairer, 2003; Collier et al., 2004). From a milk production standpoint, this is largely considered a negative outcome. However, several studies have identified a more positive outcome - keeping the animal physiologically adapted to lactation for a longer period maintains feed intake and, therefore, results in improved energy balance (Rastani et al., 2005; Pezeshki et al., 2007; de Feu et al., 2009; Jolicoeur et al., 2014). Of course, not all studies have shown improvements (e.g., Gulay et al., 2003). Given that much of the previous work has used relatively small sample sizes, a recent review extends a cautionary approach toward dry period length alterations and metabolic effects (van Knegsel et al., 2013).

Furthermore, although a substantive body of work is now available on the effects of dry period length on dairy cows, research is minimal in small ruminants. A 5-yr longitudinal examination of 6,762 lactations on one farm resulted in a broad recommendation of a 30- to 60-d dry period being appropriate for sheep (Hernandez et al., 2012). This dry period length was recommended based on milk yield and conception rate but did not consider effect on metabolic states. Interestingly, although no published research has examined this topic in goats, some producers appear to have a different perspective on the importance of the dry period and place emphasis on avoiding negative energy balance. Some producers believe that forcing their persistent goats to dry off is detrimental to energy balance and overall goat longevity and, therefore, elect to keep these animals milking (Zobel et al., 2015). These concerns echo the work of Salama et al. (2005), who suggest that because pregnancy naturally reduces milk production, an alternative approach to managing goats would be to not breed as often and focus on optimizing extended lactations, particularly in terms of improving goat longevity.

\section{The Dry Period and Intramammary Health}

The final, and largest, body of work in the dry-off literature centers on the prevention and treatment of IMI, caused by a variety of contagious and environmental pathogens. Milk losses, treatment costs, and early culling result in immense financial loss for dairy cow industries (e.g., Petrovski et al., 2006; Halasa et al., 2007; Huijps et al., 2008). In small ruminants, financial losses are not well established. Milk production losses have been recognized in sheep (Gonzalo et al., 2002, 2004); nonetheless, treatment options have only received minimal attention (e.g., Linage and Gonzalo, 2008; Spanu et al., 2011). Furthermore, debate about the financial feasibility of treatment exists in goats (Sanchez et al., 1999; Contreras et al., 2003; Koop et al., 2010; McDougall et al., 2010), with unclear milk production losses (Leitner et al., 2004; Koop et al., 2010) likely fueling this discussion.

Although IMI can occur at any point in lactation, a collection of studies have demonstrated that cows are at highest risk around the dry period (see reviews by Dingwell et al., 2003; Bradley and Green, 2004). Although not well studied, sheep (Watson and Buswell, 1984; Gonzalo et al., 2004) and goats (Leitner et al., 2007b) appear to follow a similar pattern. New IMI are most likely to occur at either 1 of 2 time periods during the dry period. The first of these is during the first stage of dry-off, as the mammary gland begins moving from a lactating state to a nonlactating state (i.e., involution). A fully involuted mammary gland is unlikely to develop an IMI (Bradley and Green, 2004). As involution occurs, the mammary environment changes to help prevent IMI. First, increasing lactoferrin activ- 
ity in the mammary gland inhibits bacterial growth, because of the ability of this protein to bind with iron that some pathogens would otherwise use (Sordillo et al., 1997). Second, the lactoferrin, in conjunction with increased levels of immunoglobulins ( $\operatorname{IgG})$, act against major gram-negative bacteria (Bushe and Oliver, 1987). Third, as fat globulins and casein concentrations decrease, leukocyte concentration and activity increase, which improves the ability of the mammary gland to resist infection. Interestingly, recent evidence suggests milk production level affects leukocyte populations. For example, cows that entered the dry period producing less than $14 \mathrm{~kg} / \mathrm{d}$ produced higher numbers of lymphocytes and macrophages, giving the mammary glands a more effective antibacterial response when compared with cows producing more than $25 \mathrm{~kg} / \mathrm{d}$ (Silanikove et al., 2013). Clearly, the beginning of the dry period is a high-risk time for IMI, but this risk can be decreased by reducing milk production before dry-off.

The second period of bacterial sensitivity in the dry period is when the mammary gland begins shifting from a nonlactating state to a lactating state late in the dry period (i.e., during colostrogenesis). This period begins approximately 1 wk before parturition (Oliver and Mitchell, 1983), as the main protective barriers of the gland against bacteria disappear (Bradley and Green, 2004). The teat cisterns begin to dilate and the keratin plugs break down, providing a potential infection route for pathogens (Oldham et al., 1991). Furthermore, increases in MEC secretory activity result in a dilution and activity of lactoferrin, IgG, and leukocytes (Sordillo and Nickerson, 1988).

The economic implications of IMI, coupled with the high risk of developing infections during the dry period, have fueled dozens of studies examining the link between the dry period to new and persistent IMI. Research has focused on a variety of subjects, including classification of the pathogens causing dry period IMI (e.g., Bradley, 2002; Contreras et al., 2003; Green et al., 2007; Barkema et al., 2009) and the development of efficient and cost-effective monitoring and identification methodologies, such as SCC (Dohoo and Leslie, 1991), California Mastitis Test (Sanford et al., 2006; Bhutto et al., 2012), and on-farm bacteriological testing (Cameron et al., 2013; Cameron et al., 2014). The latter type of research is minimal in sheep and goats, likely because identification has not been as easy in small ruminants as it has been in cows, particularly in regard to SCC. Measuring SCC is not as straightforward in small ruminants (Paape et al., 2001; Raynalljutovac et al., 2007), because in addition to indicating presence of bacteria (Koop et al., 2012), SCC is also sensitive to age and stage of lactation (Luengo et al., 2004; Paape et al., 2007; Kern et al., 2013; Persson et al., 2014). Identification issues (resulting in potentially underestimated prevalence), coupled with low animal replacement costs, are likely culprits for the bulk of research on dry period IMI prevention being focused on dairy cows.

In addition to work exploring pathogen types and identification of infection, a huge amount of research has focused on prevention. Vaccines in dairy cows have received some attention (reviewed by Middleton et al., 2009), as have the use of subcutaneous injection of antibiotics for preventing infections in the next lactation in sheep (Croft et al., 2000). However, the largest focus has been on intramammary "dry cow therapy" (for the purpose of this review, this will be referred to as "dry-off therapy" to include sheep and goats). Adoption of this practice has soared in cows since its introduction into even the earliest of mastitis prevention protocols (e.g., Neave et al., 1969). Dry-off therapy includes long-acting intramammary antibiotics, which have been widely acclaimed for their prevention of new, and treatment of existing, dry period IMI caused by contagious, gram-positive bacteria (e.g., Bradley and Green, 2004; Halasa et al., 2009; Dufour et al., 2011). Despite dry period antibiotics having been tested and encouraged in sheep (Gonzalo et al., 2004; Linage and Gonzalo, 2008; Spanu et al., 2011) and in goats (Plommet and Bézard, 1974; Fox et al., 1992; Poutrel et al., 1997; McDougall and Anniss, 2005), little evidence exits that they are actually actively used in dairy sheep and goat industries. A likely determinant of this situation is the contradictory evidence for treatment efficacy, and necessity, particularly in goats. Some authors have suggested that applying dry period antibiotics may not be worth the investment, due to the propensity of goats to self cure (Paape et al., 2001; Bergonier et al., 2003). Others support the use of dry period antibiotics either selectively (e.g., only administered to infected animals: Fox et al., 1992; McDougall and Anniss, 2005) or via blanket use (e.g., administered to all animals: Poutrel et al., 1997). Interestingly, although useful for curing existing IMI, unclear evidence exists supporting the use of dry period antibiotics for the prevention of new IMI in sheep (Gonzalo et al., 2004; Linage and Gonzalo, 2008; Spanu et al., 2011) and goats (Paape et al., 2001; McDougall and Anniss, 2005).

Despite proven efficacy and widespread use in cows, dry period antibiotics have limitations. First, the efficacy of the antibiotic decreases over time, becoming ineffective at the end of the dry period (Oliver et al., 1990; Pinedo et al., 2012). Thus, the udder resumes a state where it will once again be susceptible to gram-positive bacteria that can also be found in the environment. Second, animals remain vulnerable to environmental, gram-negative bacteria for which the majority of dry 
period antibiotics have limited effect. Indeed, because of the immense success of dry period antibiotics, environmental bacteria are now the most common causes of new IMI during the dry period (Bradley and Green, 2004). Although products aimed at addressing these bacteria are entering the market, their efficacy is still being determined (e.g., Arruda et al., 2013).

In addition to antibiotics, internal teat sealers and external sealants have been added to dry-off therapy, with the purpose of keeping pathogens out of the teat canal (reviewed by Rabiee and Lean, 2013). Although a keratin plug is supposed to form after involution occurs, teat canals may stay open throughout the dry period in some animals (Dingwell et al., 2003). The use of teat sealers and sealants has been extensively examined in cows, and treatment and prevention efficacy have been proven with (Godden et al., 2003), and in some cases without (Huxley et al., 2002; Bhutto et al., 2011), the combination of antibiotics. Of particular interest is the study by Huxley et al. (2002), who reported finding that teat sealers were especially useful for preventing environmental pathogens, a growing area of concern as contagious pathogens are being controlled by dry period antibiotics. To date, no research has reported on the efficacy of these products in sheep or goats.

As a final point, in line with the intended purpose of the aforementioned teat sealers and sealants, early dry period IMI prevention research focused on using reduced milk production to prevent IMI (Bushe and Oliver, 1987). With the advent of dry period antibiotics, as well as teat sealers and sealants, the importance of reduced milk production was largely ignored. However, the topic of reducing milk production before dry-off has recently received renewed attention. Cows entering the dry period with high milk production are more likely to develop IMI (Rajala-Schultz et al., 2005). Furthermore, these high-production cows experience more milk leakage, have delayed teat canal plug formation, as well as display differences in mammary gland response to infection (Bertulat et al., 2013; Silanikove et al., 2013). All this occurs in spite of widespread dry-off therapy use. Perhaps rather than concentrating future research on developing means of treating and preventing the still problematic IMI caused by environmental pathogens, it may be advantageous to identify the factors at the beginning of dry-off that affect susceptibility through to parturition. Furthermore, abrupt dry-off coupled with dry-off therapy may not be appropriate for highproduction cows, and alternatives need to be explored. This may become increasingly important, particularly as blanket application of antibiotics becomes more of a public concern (Bos et al., 2013; see also review by Barkema et al., 2015) and interest grows in the imple- mentation of selective dry-off therapy (Scherpenzeel et al., 2014).

As has been demonstrated by the numerous reviews and original research cited, the biological aspects and health implications of the dry period have received significant attention in the literature. On the contrary, only a small fraction of dry period research has examined the effect of dry-off on the affective states of the individual dairy animal. Regardless if they receive dry-off therapy, all dairy animals enter the dry period after a series of routine changes in management practice. Some of these changes have been suggested to cause negative affective states such as hunger, pain, and frustration.

\section{AFFECTIVE STATES}

To understand how the dairy animal experiences cessation of milking, it is important to first recap the dramatic change in milk production that has been witnessed in the last 4 decades. We use the modern dairy cow as an example. The ultimate goal of dry-off is to stop milk production, and before the widespread adoption of dry-off therapy regimens, dry-off was achieved by reducing milking frequency (Natzke et al., 1975) and providing a lower energy diet, thereby reducing milk production and ensuring the lowest possible IMI risk (Bushe and Oliver, 1987). The incorporation of dry-off therapy into recommended dry-off protocols (e.g., National Mastitis Council Recommended Mastitis Control Program; NMC, 2006) has resulted in a move to milking being stopped abruptly, with little consideration placed on how this practice may affect the affective state of the animal. However, as concern for animal welfare grows in the dairy industry (e.g., von Keyserlingk et al., 2009), identifying and addressing the negative consequences of dry-off practices is being given more consideration in the literature (Bertulat et al., 2013; Silanikove et al., 2013; Chapinal et al., 2014). One reason for this interest is that the production level of the modern cow has greatly increased. In 1975, a cow in the United States was producing an average of $15 \mathrm{~kg} / \mathrm{d}$ in a standard 305-d lactation (USDA, 2012), and it was common for cows to be below $9 \mathrm{~kg} / \mathrm{d}$ at the end of their lactation (Natzke et al., 1975). Almost 4 decades later, the average 305-d lactation has more than doubled (USDA, 2012), and with that has come higher milk production at the end of lactation (e.g., $24 \mathrm{~kg} / \mathrm{d}$, Chapinal et al., 2014), and even higher in cows treated with bST (e.g., 26-30 kg/d, Annen et al., 2004). Given such high endof-lactation milk production levels, some researchers have questioned the appropriateness of abrupt cessation of milking, namely because it is not well understood how the animals experience this practice. For instance, 
it has been argued that cows may experience pain if milk production is not first reduced (Bertulat et al., 2013; Silanikove et al., 2013). Interestingly, the act of reducing milk production (e.g., by reducing or withholding feed), may itself be detrimental to the welfare of the animal, by causing the cows to experience hunger (Valizaheh et al., 2008). Furthermore, it has been suggested that cows are motivated to be milked and that even changing their routine suddenly can be a negative experience (Zobel et al., 2013).

\section{Hunger Caused by Dietary Changes}

Decades of nutritional research have resulted in the formulation of diets that promote high milk production in cows (Stefanon et al., 2002). These diets are beneficial to the annual milk yield of the cow (and arguably the profitability of the farm), but this also makes cessation of lactation more difficult. A similar trend is likely for the growing commercial dairy goat industry, where milk production is increasing with improvements in diet formulations (e.g., Monzón-Gil et al., 2010; Goetsch et al., 2011), and many goats already have a tendency for production persistency (Gipson and Grossman, 1990). Given these changes, it is not surprising that interest has increased in determining how changes in feeding management can facilitate dry-off. The effect of a reduced energy diet on decreasing milk production in cows at, or shortly before, dry-off is well established (e.g., Bushe and Oliver, 1987; Tucker et al., 2009; Ollier et al., 2014). However, minimal work has examined how these dietary changes affect hunger at this time.

Reduced energy intake can be achieved by formulating a TMR with less energy dense feedstuffs (e.g., reduced concentrate levels), increased levels of less palatable forage, or by feeding only forage. The difficulty is achieving the end goal (reduced milk production) without compromising the animal metabolically (Odensten et al., 2007) and without inducing hunger (Valizaheh et al., 2008). Hunger is a negative affective state experienced by an animal that is not able to reach satiety (D'Eath et al., 2009). In the case of dairy animals at dry-off, the effects of hunger are likely to be short-term but still may have a negative effect on welfare. Behavioral observations are typically used to identify hunger (reviewed by D'Eath et al., 2009). In adult cows, vocalizations can be linked to periods of distress for the cow, including social isolation, pain, and hunger (Watts and Stookey, 2000). One technique to reduce milk production at dry-off is to provide readily palatable feed but in restricted amounts. Using this approach, Tucker et al. (2009) reduced IMI risk factors such as milk leakage but noted an increase in vocalizations in cows receiving only $50 \%$ of their previous ra- tion compared with cows receiving $100 \%$. The authors indicated that the 2 treatment groups were located within visual proximity of one another, so it is possible that the continued feeding behavior by animals within the treatment groups offered the full ration instigated the vocal response in the restricted dietary treatment groups. Therefore, it is not possible to determine whether the increased vocalizations were truly indicative of hunger or whether they were the result of cows being frustrated by seeing feed and not being able to access it. An alternative approach to reducing milking production at dry-off is to reduce the palatability of a freely available feed. Valizaheh et al. (2008) found that cows offered free access to oat hay vocalized more than cows offered grass hay, leaving the authors to conclude that the cows fed oat hay were hungrier. Indeed, the grass hay was more palatable, and cows ingested almost twice as much of it as those offered oat hay. The grass hay also contained one-third more protein. Studies in humans indicate that higher levels of protein help promote satiety, preventing hunger (Veldhorst et al., 2008; Johnstone, 2013). In Valizaheh et al. (2008), both hay options reduced milk production to below 10 $\mathrm{kg} / \mathrm{d}$ within $2 \mathrm{~d}$, suggesting that future research could focus on identifying feed options that are palatable and perhaps promote better satiety via alteration of protein levels. This proposed work could also include an IMI prevention component. Bushe and Oliver (1987) showed the advantages of pairing gradual milk cessation with a change in feed quality on the immune defenses of the mammary gland, which is particularly pertinent as concern over blanket use of dry period antibiotics grows (Scherpenzeel et al., 2014).

\section{Pain Due to Abrupt Cessation of Milking}

"Pain" and "discomfort" are terms frequently used in conjunction with one another. The International Association for the Study of Pain defines pain as "an unpleasant sensory and emotional experience associated with actual or potential tissue damage" (IASP, 1994). The term "discomfort" is not clearly defined in the scientific literature. Thus, although the minimal research available examining affective states around dry-off often uses "pain" and "discomfort" interchangeably, within this review, the word "pain" will be used.

Considering the above definition, abrupt cessation of milking can potentially cause pain. After milking is ceased, mammary tissue becomes engorged with milk, causing intramammary pressure (Peaker, 1980). This pressure can lead to tissue damage, resulting in pain (Bertulat et al., 2013; Silanikove et al., 2013). In humans, abrupt cessation of milking is not recommended given its propensity to cause milk leakage, engorgement, and 
pain (Betzold, 2007; Lawrence and Lawrence, 2011). The cisternal structure of the udder in cows (Davis et al., 1998), sheep (Ruberte et al., 1994), and goats (Salama et al., 2004) allows for a much larger storage capacity potential than the cistern-lacking human breast (Ramsay et al., 2005). Nonetheless, if storage capacity reaches its threshold, which may be the case in high-production cows, sheep, and goats, tissue damage and associated pain are possible.

Challenges inherent with measuring pain directly have resulted in researchers using indirect measures. Silanikove et al. (2013) suggested that increased vocalizations were indicative of udder engorgement-related pain when milking was ceased abruptly in cows producing more than $25 \mathrm{~kg} / \mathrm{d}$. Because all cows received the same change in diet, it is unlikely that these vocalizations were caused by hunger. Other researchers have focused on changes in lying behavior. In lactating cows, decreased lying time has been attributed to milk accumulation and the resulting udder pressure caused by omitted milkings (O'Driscoll et al., 2011) and by reduced milking frequencies (Österman and Redbo, 2001). At dry-off, lying behavior responses to cessation of milking are less conclusive. Tucker et al. (2009) found no effect on lying time when cows were abruptly dried off; however, average milk production was below 10 $\mathrm{kg} / \mathrm{d}$, and udder firmness increased minimally. Chapinal et al. (2014) noted a change in lying behavior only in primiparous cows ending their first lactation. Furthermore, a comparison of abrupt cessation of milking with gradually reduced milking yielded no difference in lying time of high-production cows (e.g., $19-35 \mathrm{~kg} / \mathrm{d}$, Zobel et al., 2013), but the change in diet to higher forage content resulted in increased feeding time, which confounded any changes of lying behavior in both treatments. Conversely, Leitner et al. (2007a) demonstrated that cows producing $25 \mathrm{~kg} / \mathrm{d}$ at dry-off and treated with intramammary casein hydrolyzate, which reduces intramammary pressure and engorgement by accelerating the involution process, spent more time lying down than nontreated cows. Udder firmness in untreated cows increased for the first $4 \mathrm{~d}$, whereas it immediately decreased in the treated cows. Although Zobel et al. (2013) did not measure udder firmness when comparing abrupt milk cessation to reduced milking frequency before dry-off, the difference in milk production between these treatments was only $3.3 \mathrm{~kg}$ at the final milking. It is therefore possible that engorgement did not differ enough between the treatments to alter lying behavior. Future work evaluating lying behavior as a pain indicator in cows should take into account milk production at dry-off.

Work examining how small ruminants experience cessation of milking is lacking. Similar to cow work ex- amining dry-off methodology, Petridis et al. (2013) exposed dairy ewes to either having their milking ceased abruptly or having it gradually reduced over a period of $22 \mathrm{~d}$. Unfortunately, the focus of this work was entirely on mammary health, and no consideration was given to possible indicators of pain such as udder firmness or behavioral changes.

\section{Frustration Due to Abrupt Cessation of Milking}

As with the measurement of pain, measuring frustration must also be done indirectly. Keeling et al. (2008) proposed that when an animal is motivated to acquire something, it initiates a reward cycle where the highest positive affective state occurs once the reward is acquired. Thus, it can be argued that when a cow has been conditioned to be milked a set number of times in the day, thwarting the motivation of a cow to be milked at these milking times (as would occur with abrupt cessation of milking) would not allow for the completion of the reward cycle. When this occurs, animals may display abnormal behaviors. It has been suggested that the display of nonfunctional behaviors can be an indicator of frustration when an animal cannot perform something it is motivated to do (e.g., Dawkins, 1988). Using this premise, a small number of studies have explored frustration in relation to milking routine changes, all of which have focused on standing behavior. For instance, Stefanowska et al. (2000) concluded that increased standing at the pen's exit gate was associated with missed milkings in lactating cows. Furthermore, when cows were either dried off via a series of skipped milkings over 5 d or via an abrupt cessation of milking, the latter were 5 times more likely to wait at the gate compared with before dry-off (Zobel et al., 2013). This increased waiting was suggested to be in response to frustration caused by both a change in routine and by pain from udder engorgement. Interestingly, cows that were subjected to the series of skipped milkings did not demonstrate an increase in standing at the gate. This follows the results of Tucker et al. (2007), who transitioned cows from twice- to once-a-day milking with no increase in standing at the gate. Collectively, these findings are in alignment with a broader realm of literature demonstrating that performing management changes gradually reduces the negative behavioral responses relative to when those changes are performed abruptly (e.g., weaning of beef calves: Price et al., 2003; Loberg et al., 2008; early introduction to milking parlor of buffalo heifers: Polikarpus et al., 2014).

It is clear that cows are responding to changes in management associated with dry-off; however, more conclusive research is needed to determine what level of change minimizes negative affective states such as 
frustration. Studies using methods intended to evaluate motivation for access to a resource, such as the distance a cow will walk for access to pasture (Charlton et al., 2013) and food (Schütz et al., 2006), could, for instance, be applied to assessing how motivated a cow is to be milked. Operant tasks, where animals are trained to work to obtain a resource, could also be used, such as pressing a lever (e.g., horses: Søndergaard et al., 2011) or pushing through weighted doors or gates (e.g., sheep: Jackson et al., 1999; cichlid fish: Galhardo et al., 2011). Because cows have shown that they will stand by the gate during milking time, a logical way to measure motivation would be to teach them to push on that gate before dry-off. Motivation for milking after dry-off could then be assessed by measuring how much weight the cows would be willing to push to access the milking parlor.

\section{NATURAL LIVING}

In most mammals, the natural tendency is for the dam to produce enough milk for her offspring. As dependency on the dam decreases, offspring nurse less often. This decrease in dependency has been noted in feral cattle (Vitale et al., 1986) as well as managed Zebu populations, where calves were given restricted access to their dams for short bouts after milking each day (Das et al., 2000). The lactation cycle cultivated by the modern dairy industry deviates immensely from this natural system. This deviation has occurred in several key ways, including the way milking is ceased, the actual amount of milk being produced, and, of course, the separation of the dam from her offspring.

\section{Cessation of Milking}

In natural systems, milk production is closely tied to the needs of the offspring. When the demand for milk declines, milk production naturally diminishes due to gradual involution (Wilde et al., 1997). Milk production ebbs further if the cow (Olori et al., 1997), sheep (Pollott and Gootwine, 2004), or goat (Knight and Wilde, 1988) is pregnant. Conversely, in commercial systems, although a certain amount of gradual involution occurs after lactation peaks, milk production often remains high even late into gestation, particularly in cows. Furthermore, the removal of milk from the udder is typically ceased abruptly. This involves the mammary gland going through acute involution, a process that in nature would be relatively rare. With the exception of a loss of offspring in nature, the amount of acute involution experienced by modern cows, and perhaps goats, is entirely a construct of the modern dairy industry. Acute involution is discouraged in humans.
As mentioned previously, pain is a major concern, but more recently, serious health outcomes have also been suggested (e.g., increased risk of breast cancer; Silanikove, 2014). Differences in physiological responses to forced acute involution between low-producing and high-producing cows have been shown (Silanikove et al., 2013). These differences are likely due to the lowproducing animals having already undergone a more natural involution process. The driving factors behind some animals approaching dry-off with lower milk production have not been the focus of much research, because it is contradictory to increased overall milk production. Nonetheless, these animals are following a more natural lactation cycle and should therefore be included in future work aimed at understanding how cows actually experience the currently used unnatural lactation cycle.

\section{Milk Production and Lactation Cycle}

In decades past, there was a focus on reducing milk production before dry-off. It is likely that this practice originated because it closely matched the natural lactation cycle (e.g., where a calf would take 8-12 mo to slowly cease suckling; Reinhardt et al., 1986), but the udder health benefits of this practice were also demonstrated (e.g., Natzke et al., 1975). Regardless of the reasoning for implementing the practice, priority for reducing milk production before dry-off diminished as dry-off therapy antibiotics and sealants became widely used. Current dry-off practices are almost entirely focused on fitting an annual lactation cycle and rarely consider production level. Indeed, the modern Holstein cow is now dried off when she is producing what a cow in 1975 would have produced at peak lactation (Figure 1). Models predict that it may take more than $700 \mathrm{~d}$ after parturition for a modern cow to reach milk production levels (Cole et al., 2011) that were once considered appropriate for drying off. With this information in mind, it is possible that the 305-d lactation cycle simply does not apply to the modern cow and that longer lactations would be beneficial. It has been suggested that exploring unconventional lactation lengths in cows could help with some of the current issues being faced by the dairy industry, including reproduction issues (Pryce et al., 2004; Chagas et al., 2007). Indeed, several studies have explored and demonstrated the feasibility of extended lactation lengths in dairy cows (e.g., Arbel et al., 2001; Österman et al., 2005; Butler et al., 2010). In intensive systems, extending the lactation to 18 mo was found to have no negative effect on fertility (Ratnayake et al., 1998) or udder health (Österman et al., 2005) and to have a positive effect on overall milk production (Österman and Bertilsson, 2003). Similar benefits have 


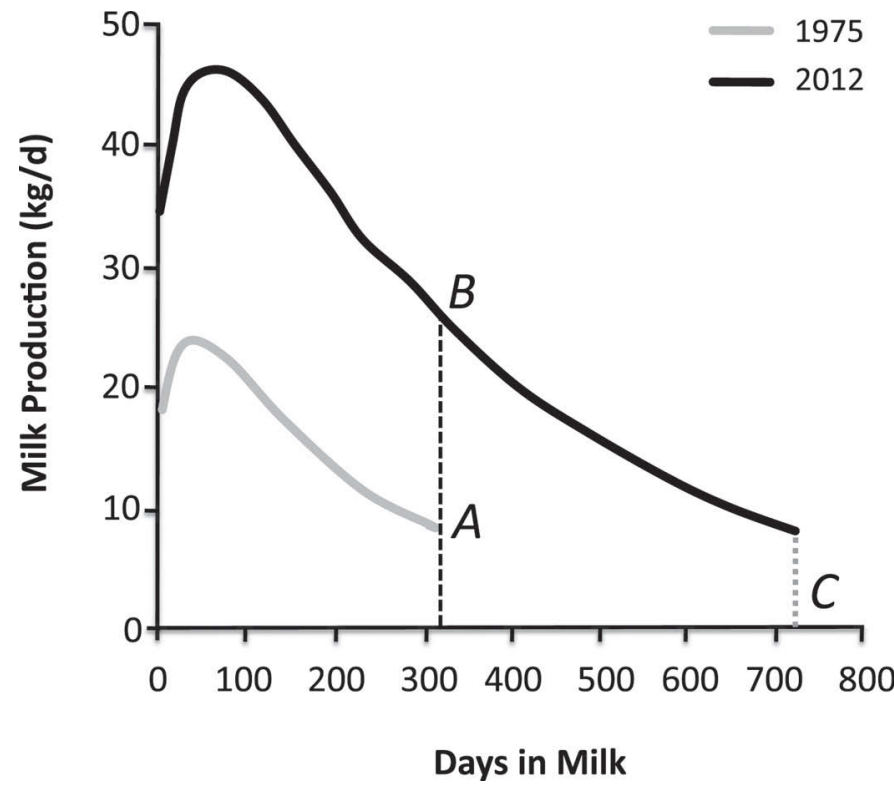

Figure 1. Example dairy cow lactation curves for 1975 (solid gray line) and 2012 (solid black line). Vertical black dashed line denotes dryoff according to standard 305-d lactation management. Estimated milk production at dry-off presented for 1975 (A) and for 2012 (B). Vertical gray dotted line $(\mathrm{C})$ denotes the estimated number of days in milk required for a cow to reach the milk production at dry-off achieved in 1975. Lactation curve for 1975 estimated according to Natzke et al. (1975) and USDA (2012). Lactation curve for 2012 adapted from Cole et al. (2011) and USDA (2012)

been noted in pasture-based systems as well, with both 22-mo (Auldist et al., 2007; Kolver et al., 2007) and 24-mo (Butler et al., 2010) lactation lengths resulting in milk-production and overall health benefits for the cows.

In goats, some animals tend to have persistent milk production (Safayi et al., 2010), resulting in more variable lactation cycles (García-Peniche et al., 2012) than those of cows. As previously mentioned, the minimal work examining dry-off and dry periods in goats suggests that extended lactations, with and without dry periods, are a possibility (Fowler et al., 1991; Safayi et al., 2010; Douhard et al., 2013). Furthermore, some farmers actively try to manage goats based on their individual milk production, resulting in some goats being milked continuously, even when pregnant (Zobel et al., 2015). This latter work suggests that flexibility in lactation management sometimes implemented in goats could potentially inform dairy cow management in regard to parturition-related disease. Although goats are susceptible to some kidding-related conditions (e.g., ketosis), these appear to be lower in prevalence (Melby et al., 1986; Zobel et al., 2015) compared with cows (McArt et al., 2012). It has been suggested that allowing goats to continue milking for longer periods can help in reducing the risk of ketosis (Zobel et al., 2015).

\section{Revisiting the Naturalness of the Lactation Cycle of the Dairy Animal}

Abrupt cessation of lactation and dramatically increased milk production aside, arguably the biggest deviation of all in terms of how modern dairy practices have altered the lactation cycle from its natural state is the separation of the dam and offspring. Consumer concern over this practice is growing (Ventura et al. 2013) and is in turn motivating research (e.g., Johnsen et al., 2015). It is quite possible that this desire to explore how the early parts of lactation are handled will affect how the entire lactation, including its cessation, is managed. Some of the health issues that are at least partially attributed to dry period management could actually be indirectly addressed by returning to a more natural lactation cycle. For instance, it has been suggested that some of the current longevity issues of the modern dairy cow stem from not allowing natural suckling (e.g., see review by Krohn, 2001). Some research has shown that allowing the calves to suckle the dams improves mammary health. Walsh (1974) found a dramatic difference in IMI incidence between cows that were suckled (2\%) versus milked $(29 \%)$ in the first 8 wk of lactation. Similarly, Fröberg et al. (2008) found a tendency for decreased SCC when cows were milked normally but were also suckled by their calf. Furthermore, it has been suggested that a more natural lactation cycle tends to delay estrous (Krohn, 2001), subsequently delaying when conception is possible. Although the fertility benefits of this may seem counterintuitive, Tenhagen et al. (2003) demonstrated that delaying insemination by a cycle (i.e., $3 \mathrm{wk}$ ) dramatically improved conception rates, for both low- and high-milk-production cows. This illustrates merit in revisiting the idea of returning a level of naturalness to the way the dairy industries manage lactations. Benefits could be far reaching, including positive mammary health, reproduction improvements, and longer lactations that near the dry-off period at a more reasonable production level. Although it would mean a dramatic shift in how current lactation management is viewed, dairy industries may soon be motivated (or mandated) by consumer demand to employ more natural lactation cycles.

\section{SUMMARY}

Dry-off research in dairy animals began decades ago and has resulted in an immense amount of literature, particularly in cattle. The majority of this is focused on aspects of biological functioning and animal health, but this review has identified clear gaps in our knowledge in regard to dry-off and the dry period. First, few studies 
have examined affective states such as pain, hunger, and frustration caused by management related to dryoff. Current management of cows was established decades ago and is likely outdated for the production level of the modern dairy cow. In sheep and goats, there is a dearth of research describing dry-off management practices and how dry-off affects affective states. Second, we have deviated drastically from natural lactation patterns, forcing an annual lactation cycle and set dry periods onto modern dairy animals. Quantifying how this deviation affects welfare is difficult, but some work looking at indirect measures, such as the metabolic health outcomes of set dry period lengths in cows, has pointed out detrimental effects of current management. Work is needed in both cows and small ruminants to assess the potential benefits of working more within the natural lactation tendencies of the animals.

\section{ACKNOWLEDGMENTS}

Gosia Zobel was supported by Canada's Natural Science and Engineering Research Council's PGSD Scholarship (Ottawa, ON, Canada). M. A. G. von Keyserlingk and D. M. Weary are supported by Canada's Natural Sciences and Engineering Research Council (NSERC) Industrial Research Chair Program with industry contributions from the Dairy Farmers of Canada (Ottawa, ON, Canada), British Columbia Dairy Association (Burnaby, BC Canada), Westgen Endowment Fund (Milner, BC, Canada), Intervet Canada Corporation (Kirkland, QC, Canada), Zoetis (Kirkland, QC, Canada), Novus International Inc. (Oakville, ON, Canada), BC Cattle Industry Development Fund (Kamloops, BC, Canada), Alberta Milk (Edmonton, AB, Canada), Valacta (St. Anne-de-Bellevue, QC, Canada), and CanWest DHI (Guelph, ON, Canada).

\section{REFERENCES}

Annen, E. L., R. J. Collier, M. A. McGuire, J. L. Vicini, J. M. Ballam, and M. J. Lormore. 2004. Effect of modified dry period lengths and bovine somatotropin on yield and composition of milk from dairy cows. J. Dairy Sci. 87:3746-3761.

Arbel, R., Y. Bigun, E. Ezra, H. Sturman, and D. Hojman. 2001. The effect of extended calving intervals in high lactating cows on milk production and profitability. J. Dairy Sci. 84:600-608.

Arruda, A. G., S. Godden, P. Rapnicki, P. Gorden, L. Timms, S. S. Aly, T. W. Lehenbauer, and J. Champagne. 2013. Randomized noninferiority clinical trial evaluating 3 commercial dry cow mastitis preparations: I. Quarter-level outcomes. J. Dairy Sci. 96:4419-4435.

Auldist, M. J., G. O'Brien, D. Cole, K. L. Macmillan, and C. Grainger. 2007. Effects of varying lactation length on milk production capacity of cows in pasture-based dairying systems. J. Dairy Sci. 90:3234-3241.

Bachman, K. C. 2002. Milk production of dairy cows treated with estrogen at the onset of a short dry period. J. Dairy Sci. 85:797-803.
Bachman, K. C., and M. L. Schairer. 2003. Invited review: Bovine studies on optimal lengths of dry periods. J. Dairy Sci. 86:30273037.

Barkema, H. W., M. J. Green, A. J. Bradley, and R. N. Zadoks. 2009. Invited review: The role of contagious disease in udder health. J. Dairy Sci. 92:4717-4729.

Barkema, H. W., M. A. G. von Keyserlingk, J. P. Kastelic, T. J. G. M. Lam, C. Luby, J.-P. Roy, S. J. LeBlanc, G. P. Keefe, and D. F. Kelton. 2015. Invited review: Changes in the dairy industry affecting dairy cattle health and welfare. J. Dairy Sci. 98:7426-7445. http://dx.doi.org/10.3168/jds.2015-9377.

Bergonier, D., R. de Crémoux, R. Rupp, G. Lagriffoul, and X. Berthelot. 2003. Mastitis of dairy small ruminants. Vet. Res. 34:689-716.

Bernier-Dodier, P., C. L. Girard, B. G. Talbot, and P. Lacasse. 2011. Effect of dry period management on mammary gland function and its endocrine regulation in dairy cows. J. Dairy Sci. 94:4922-4936.

Bertulat, S., C. Fischer-Tenhagen, V. Suthar, E. Möstl, N. Isaka, and W. Heuwieser. 2013. Measurement of fecal glucocorticoid metabolites and evaluation of udder characteristics to estimate stress after sudden dry-off in dairy cows with different milk yields. J. Dairy Sci. 96:3774-3787.

Betzold, C. M. 2007. An update on the recognition and management of lactational breast inflammation. J. Midwifery Womens Health 52:595-605.

Bhutto, A. L., R. D. Murray, and Z. Woldehiwet. 2011. The effect of dry cow therapy and internal teat-sealant on intra-mammary infections during subsequent lactation. Res. Vet. Sci. 90:316-320.

Bhutto, A. L., R. D. Murray, and Z. Woldehiwet. 2012. California mastitis test scores as indicators of subclinical intra-mammary infections at the end of lactation in dairy cows. Res. Vet. Sci. 92:13-17.

Bos, M. E. H., F. J. Taverne, I. M. van Geijlswijk, J. W. Mouton, D. J. Mevius, and D. J. J. Heederik. 2013. Consumption of antimicrobials in pigs, veal calves, and broilers in the Netherlands: Quantitative results of nationwide collection of data in 2011. PLoS ONE 8:e77525.

Bradley, A. J. 2002. Bovine mastitis: An evolving disease. Vet. J. 164:116-128.

Bradley, A. J., and M. J. Green. 2004. The importance of the nonlactating period in the epidemiology of intramammary infection and strategies for prevention. Vet. Clin. North Am. Food Anim. Pract. 20:547-568.

Bushe, T., and S. P. Oliver. 1987. Natural protective factors in bovine mammary secretions following different methods of milk cessation. J. Dairy Sci. 70:696-704.

Butler, S. T., L. Shalloo, and J. J. Murphy. 2010. Extended lactations in a seasonal-calving pastoral system of production to modulate the effects of reproductive failure. J. Dairy Sci. 93:1283-1295.

Butler, W. R., and R. D. Smith. 1989. Interrelationships between energy balance and postpartum reproductive function in dairy cattle. J. Dairy Sci. 72:767-783.

Butte, N., M. G. Lopez-Alarcon, and C. Garza. 2002. Nutrient Adequacy of Exclusive Breastfeeding for the Term Infant During the First Six Months of Life. World Health Organization, Geneva, Switzerland.

Caja, G., A. A. K. Salama, and X. Such. 2006. Omitting the dry-off period negatively affects colostrum and milk yield in dairy goats. J. Dairy Sci. 89:4220-4228.

Cameron, M., G. P. Keefe, J. P. Roy, I. R. Dohoo, K. A. MacDonald, and S. L. McKenna. 2013. Evaluation of a 3M Petrifilm on-farm culture system for the detection of intramammary infection at the end of lactation. Prev. Vet. Med. 111:1-9.

Cameron, M., S. L. McKenna, K. A. MacDonald, I. R. Dohoo, J. P. Roy, and G. P. Keefe. 2014. Evaluation of selective dry cow treatment following on-farm culture: Risk of postcalving intramammary infection and clinical mastitis in the subsequent lactation. J. Dairy Sci. 97:270-284.

Capuco, A. V., and R. M. Akers. 1999. Mammary involution in dairy animals. J. Mammary Gland Biol. Neoplasia 4:137-144.

Capuco, A. V., R. M. Akers, and J. J. Smith. 1997. Mammary growth in Holstein cows during the dry period: Quantification of nucleic acids and histology. J. Dairy Sci. 80:477-487. 
Chagas, L. M., J. J. Bass, D. Blache, C. R. Burke, J. K. Kay, D. R. Lindsay, M. C. Lucy, G. B. Martin, S. Meier, F. M. Rhodes, J. R. Roche, W. W. Thatcher, and R. Webb. 2007. Invited review: New perspectives on the roles of nutrition and metabolic priorities in the subfertility of high-producing dairy cows. J. Dairy Sci. 90:4022-4032.

Chapinal, N., G. Zobel, K. Painter, and K. E. Leslie. 2014. Changes in lying behavior after abrupt cessation of milking and regrouping at dry-off in freestall-housed cows: A case study. J. Vet. Behav. Clin. Appl. Res. 9:362-369.

Charlton, G. L., S. M. Rutter, M. East, and L. A. Sinclair. 2013. The motivation of dairy cows for access to pasture. J. Dairy Sci. 96:4387-4396

Cole, J. B., D. J. Null, and A. De Vries. 2011. Short communication Best prediction of 305-day lactation yields with regional and seasonal effects. J. Dairy Sci. 94:1601-1604.

Collier, R. J., E. L. Annen, and A. C. Fitzgerald. 2004. Prospects for zero days dry. Vet. Clin. North Am. Food Anim. Pract. 20:687-701.

Contreras, A., C. Luengo, A. Sanchez, and J. C. Corrales. 2003. The role of intramammary pathogens in dairy goats. Livest. Prod. Sci. 79:273-283.

Croft, A., T. Duffield, P. Menzies, K. Leslie, R. Bagg, and P. Dick. 2000. The effect of tilmicosin administered to ewes prior to lambing on incidence of clinical mastitis and subsequent lamb performance. Can. Vet. J. 41:306-311.

D'Eath, R. B., B. J. Tolkamp, I. Kyriazakis, and A. B. Lawrence. 2009. "Freedom from hunger" and preventing obesity: The animal welfare implications of reducing food quantity or quality. Anim. Behav. 77:275-288.

Das, S., I. Redbo, and H. Wiktorsson. 2000. Effect of age of calf on suckling behaviour and other behavioural activities of Zebu and crossbred calves during restricted suckling periods. Appl. Anim. Behav. Sci. 67:47-57.

Davis, S. R., V. C. Farr, P. J. A. Copeman, V. R. Carruthers, C. H. Knight, and K. Stelwagen. 1998. Partitioning of milk accumulation between cisternal and alveolar compartments of the bovine udder: Relationship to production loss during once daily milking. J. Dairy Res. 65:1-8.

Dawkins, M. S. 1988. Behavioural deprivation: A central problem in animal welfare. Appl. Anim. Behav. Sci. 20:209-225.

de Feu, M. A., A. C. O. Evans, P. Lonergan, and S. T. Butler. 2009 The effect of dry period duration and dietary energy density on milk production, bioenergetic status, and postpartum ovarian function in Holstein-Friesian dairy cows. J. Dairy Sci. 92:6011-6022.

DeSantiago, S., N. Torres, A. Suryawan, A. R. Tovar, and S. M. Hutson. 1998. Regulation of branched-chain amino acid metabolism in the lactating rat. J. Nutr. 128:1165-1171.

Dingwell, R. T., D. F. Kelton, and K. E. Leslie. 2003. Management of the dry cow in control of peripartum disease and mastitis. Vet. Clin. North Am. Food Anim. Pract. 19:235-265.

Dix Arnold, P. T., and R. B. Becker. 1936. Influence of preceding dry period and of mineral supplement on lactation. J. Dairy Sci. 19:257-266.

Dohoo, I., and K. Leslie. 1991. Evaluation of changes in somatic cell counts as indicators of new intramammary infections. Prev. Vet. Med. 10:225-237.

Douhard, F., N. C. Friggens, J. Tessier, O. Martin, M. Tichit, and D. Sauvant. 2013. Characterization of a changing relationship between milk production and liveweight for dairy goats undergoing extended lactation. J. Dairy Sci. 96:5698-5711.

Dufour, S., A. Fréchette, H. W. Barkema, A. Mussell, and D. T. Scholl. 2011. Invited review: Effect of udder health management practices on herd somatic cell count. J. Dairy Sci. 94:563-579.

Edmondson, M. A., and D. G. Pugh. 2004. Pregnancy toxemia in sheep and goats. Pages 144-145 in Current Veterinary Therapy: Food Animal Practice. D. E. Anderson and D. M. Rings, ed. Saunders Elsevier, St. Louis, MO.

El-Tarabany, M. S. 2015. Effects of non-lactating period length on the subsequent calving ease and reproductive performance of Holstein, Brown Swiss and the crosses. Anim. Reprod. Sci. 158:60-67.
Fowler, P. A., C. H. Knight, and M. A. Foster. 1991. Omitting the dry period between lactations does not reduce subsequent milk production in goats. J. Dairy Res. 58:13-19.

Fox, L., D. Hancock, and S. Horner. 1992. Selective intramammary antibiotic therapy during the nonlactating period in goats. Small Rumin. Res. 9:313-318.

Fraser, D., D. M. Weary, E. A. Pajor, and B. N. Milligan. 1997. A scientific conception of animal welfare that reflects ethical concerns. Anim. Welf. 6:187-205.

Fröberg, S., E. Gratte, K. Svennersten-Sjaunja, I. Olsson, C. Berg, A. Orihuela, C. S. Galina, B. García, and L. Lidfors. 2008. Effect of suckling ("restricted suckling") on dairy cows' udder health and milk let-down and their calves' weight gain, feed intake and behaviour. Appl. Anim. Behav. Sci. 113:1-14.

Galhardo, L., O. Almeida, and R. F. Oliveira. 2011. Measuring motivation in a cichlid fish: An adaptation of the push-door paradigm. Appl. Anim. Behav. Sci. 130:60-70.

García-Peniche, T. B., H. H. Montaldo, M. Valencia-Posadas, G. R. Wiggans, S. M. Hubbard, J. A. Torres-Vázquez, and L. Shepard. 2012. Breed differences over time and heritability estimates for production and reproduction traits of dairy goats in the United States. J. Dairy Sci. 95:2707-2717.

Gipson, T. A., and M. Grossman. 1990. Lactation curves in dairy goats: A review. Small Rumin. Res. 3:383-396.

Godden, S., P. Rapnicki, S. Stewart, J. Fetrow, A. Johnson, R. Bey, and R. Farnsworth. 2003. Effectiveness of an internal teat seal in the prevention of new intramammary infections during the dry and early-lactation periods in dairy cows when used with a dry cow intramammary antibiotic. J. Dairy Sci. 86:3899-3911.

Goetsch, A. L., S. S. Zeng, and T. A. Gipson. 2011. Factors affecting goat milk production and quality. Small Rumin. Res. 101:55-63.

Gonzalo, C., A. Ariznabarreta, J. A. Carriedo, and F. San Primitivo. 2002. Mammary pathogens and their relationship with somatic cell count and milk yield losses in dairy ewes. J. Dairy Sci. 85:1460-1467.

Gonzalo, C., J. A. Tardáguila, L. F. De La Fuente, and F. San Primitivo. 2004. Effects of selective and complete dry therapy on prevalence of intramammary infection and on milk yield in the subsequent lactation in dairy ewes. J. Dairy Res. 71:33-38.

Green, M. J., A. J. Bradley, G. F. Medley, and W. J. Browne. 2007 Cow, farm, and management factors during the dry period that determine the rate of clinical mastitis after calving. J. Dairy Sci. 90:3764-3776.

Gulay, M. S., M. J. Hayen, K. C. Bachman, T. Belloso, M. Liboni, and H. H. Head. 2003. Milk production and feed intake of Holstein cows given short (30-d) or normal (60-d) dry periods. J. Dairy Sci. 86:2030-2038.

Halasa, T., K. Huijps, O. Østerås, and H. Hogeveen. 2007. Economic effects of bovine mastitis and mastitis management: A review. Vet. Q. 29:18-31.

Halasa, T., O. Østerås, H. Hogeveen, T. van Werven, and M. Nielen. 2009. Meta-analysis of dry cow management for dairy cattle. Part 1. Protection against new intramammary infections. J. Dairy Sci. 92:3134-3149.

Harmeyer, J., and C. Schlumbohm. 2006. Pregnancy impairs ketone body disposal in late gestating ewes: Implications for onset of pregnancy toxaemia. Res. Vet. Sci. 81:254-264.

Hernandez, F., L. Elvira, J.-V. Gonzalez-Martin, and S. Astiz. 2012. Influence of dry period length on reproductive performance and productivity of Lacaune dairy sheep under an intensive management system. J. Dairy Res. 79:352-360.

Huijps, K., T. J. Lam, and H. Hogeveen. 2008. Costs of mastitis: Facts and perception. J. Dairy Res. 75:113-120.

Huxley, J. N., M. J. Greent, L. E. Green, and A. J. Bradley. 2002. Evaluation of the efficacy of an internal teat sealer during the dry period. J. Dairy Sci. 85:551-561.

IASP (International Association for the Study of Pain). 1994. Part III: Pain terms, a current list with definitions and notes on usage. Pages 209-214 in Classification of Chronic Pain. H. Merskey and N. Bogduk, ed. ISAP Press, Seattle, WA. 
Jackson, R. E., N. K. Waran, and M. S. Cockram. 1999. Methods for measuring feeding motivation in sheep. Anim. Welf. 8:53-63.

Johnsen, J. F., A. M. de Passillé, C. M. Mejdell, K. E. Bøe, A. M. Grøndahl, A. Beaver, J. Rushen, and D. M. Weary. 2015. The effect of nursing on the cow-calf bond. Appl. Anim. Behav. Sci. 163:50-57.

Johnstone, A. 2013. Protein and satiety. Pages 128-142 in Satiation, Satiety and the Control of Food Intake. J. E. Blundell and F. Bellisle, ed. Woodhead Publ., Cambridge, England.

Jolicoeur, M. S., A. F. Brito, D. E. Santschi, D. Pellerin, D. Lefebvre, R. Berthiaume, and C. L. Girard. 2014. Short dry period management improves peripartum ruminal adaptation in dairy cows. J. Dairy Sci. 97:7655-7667.

Keeling, L. J., B. Algers, H. Blokhuis, A. Boissy, L. Lidfors, M. Mendl, R. Oppermann-Moe, E. Paul, K. Uvnas-Moberg, and A. Zanella. 2008. Looking on the bright side of life: Reward, positive emotions and animal welfare. Page 3 in 42nd Int. Congr. ISAE Proc., Dublin, Ireland. Wageningen Academic Publishers, Wageningen, the Netherlands.

Kern, G., I. Traulsen, N. Kemper, and J. Krieter. 2013. Analysis of somatic cell counts and risk factors associated with occurrence of bacteria in ewes of different primary purposes. Livest. Sci. 157:597-604.

Khorshidie, R., A. A. Shadparvar, N. G. Hossein-Zadeh, and S. J. Shakalgurabi. 2012. Genetic trends for 305-day milk yield and persistency in Iranian Holsteins. Livest. Sci. 144:211-217.

Klein, J. W., and T. E. Woodward. 1942. Influence of length of dry period upon the quantity of milk produced in the subsequent lactation. J. Dairy Sci. 26:705-713.

Knight, C. H., and C. J. Wilde. 1988. Milk production in concurrently pregnant and lactating goats mated out of season. J. Dairy Res. 55:487-493.

Kolver, E. S., J. R. Roche, C. R. Burke, J. K. Kay, and P. W. Aspin. 2007. Extending lactation in pasture-based dairy cows: I. Genotype and diet effect on milk and reproduction. J. Dairy Sci. 90:5518-5530.

Koop, G., S. De Vliegher, A. De Visscher, K. Supré, F. Haesebrouck, M. Nielen, and T. van Werven. 2012. Differences between coagulase-negative Staphylococcus species in persistence and in effect on somatic cell count and milk yield in dairy goats. J. Dairy Sci. 95:5075-5084.

Koop, G., T. van Werven, H. J. Schuiling, and M. Nielen. 2010. The effect of subclinical mastitis on milk yield in dairy goats. J. Dairy Sci. 93:5809-5817.

Krohn, C. C. 2001. Effects of different suckling systems on milk production, udder health, reproduction, calf growth and some behavioural aspects in high producing dairy cows: A review. Appl. Anim. Behav. Sci. 72:271-280

Kuhn, M. T., J. L. Hutchison, and H. D. Norman. 2006. Dry period length to maximize production across adjacent lactations and lifetime production. J. Dairy Sci. 89:1713-1722.

Lawrence, R. A., and R. M. Lawrence. 2011. Engorgement. Pages 1078-1081 in Breastfeeding-A Guide for the Medical Professional. Mosby (Elsevier Inc.), Maryland Heights, MO.

Leitner, G., S. Jacoby, E. Maltz, and N. Silanikove. 2007a. Casein hydrolyzate intramammary treatment improves the comfort behavior of cows induced into dry-off. Livest. Sci. 110:292-297.

Leitner, G., U. Merin, Y. Lavi, A. Egber, and N. Silanikove. 2007b. Aetiology of intramammary infection and its effect on milk composition in goat flocks. J. Dairy Res. 74:186-193.

Leitner, G., U. Merin, and N. Silanikove. 2004. Changes in milk composition as affected by subclinical mastitis in goats. J. Dairy Sci. $87: 1719-1726$.

León, J. M., N. P. P. Macciotta, L. T. Gama, C. Barba, and J. V. Delgado. 2012. Characterization of the lactation curve in MurcianoGranadina dairy goats. Small Rumin. Res. 107:76-84.

Li, P., C. J. Wilde, L. M. Finch, D. G. Fernig, and P. S. Rudland. 1999. Identification of cell types in the developing goat mammary gland. Histochem. J. 31:379-393.

Linage, B., and C. Gonzalo. 2008. Influence of an intramammary infusion at drying-off of combined penethamate hydriodide, be- nethamine penicillin, and framycetin sulfate on intramammary infections and somatic cell counts in dairy sheep. J. Dairy Sci. 91:3459-3466.

Loberg, J. M., C. E. Hernandez, T. Thierfelder, M. B. Jensen, C. Berg, and L. Lidfors. 2008. Weaning and separation in two steps-A way to decrease stress in dairy calves suckled by foster cows. Appl. Anim. Behav. Sci. 111:222-234.

Luengo, C., A. Sanchez, J. C. Corrales, C. Fernandez, and A. Contreras. 2004. Influence of intramammary infection and non-infection factors on somatic cell counts in dairy goats. J. Dairy Res. 71:169-174.

Marteniuk, J. V., and T. H. Herdt. 1988. Pregnancy toxaemia and ketosis of ewes and does. Vet. Clin. North Am. Food Anim. Pract. 4:307-315.

McArt, J. A. A., D. V. Nydam, and G. R. Oetzel. 2012. Epidemiology of subclinical ketosis in early lactation dairy cattle. J. Dairy Sci. 95:5056-5066.

McDougall, S., and F. Anniss. 2005. Efficacy of antibiotic treatment at drying-off in curing existing infections and preventing new infections in dairy goats. Pages 523-528 in Mastitis in Dairy Production, Current Knowledge and Future Solutions. H. Hogeveen, ed. Wageningen Acad. Publ., Wageningen, the Netherlands.

McDougall, S., K. Supré, S. De Vliegher, F. Haesebrouck, H. Hussein, L. Clausen, and C. Prosser. 2010. Diagnosis and treatment of subclinical mastitis in early lactation in dairy goats. J. Dairy Sci. 93:4710-4721.

Melby, H. P., J. Aursjø, M. Binde, and H. Grøstøl. 1986. Disease in 27 Norwegian dairy goat farms. Nord. Vet. Med. 38:403-411.

Middleton, J. R., C. D. Luby, and D. S. Adams. 2009. Efficacy of vaccination against staphylococcal mastitis: A review and new data. Vet. Microbiol. 134:192-198.

Monzón-Gil, E., J. I. R. Castañón, and M. R. Ventura. 2010. Effect of low-forage rations on milk production of dairy goats: Separate concentrate-forage versus mixed rations. Small Rumin. Res. 94:196-200.

Mulligan, F. J., and M. L. Doherty. 2008. Production diseases of the transition cow. Vet. J. 176:3-9.

Natzke, R. P., R. W. Everett, and D. R. Bray. 1975. Effect of drying off practices on mastitis infection. J. Dairy Sci. 58:1828-1835.

Neave, F. K., F. H. Dodd, R. G. Kingwill, and D. R. Westgarth. 1969. Control of mastitis in the dairy herd by hygiene and management. J. Dairy Sci. 52:696-707.

Neville, M. C. 1983. Regulation of mammary development and lactation. Pages 104-140 in Lactation-Physiology, Nutrition and Breast-feeding. M. C. Neville and M. R. Niefert, ed. Plenum Press, New York, NY.

NMC (National Mastitis Council). 2006. NMC Factsheet-Dry Cow Therapy. Accessed Nov. 21, 2014. http://nmconline.org/drycow. htm.

O'Driscoll, K., D. Gleeson, B. O'Brien, and L. Boyle. 2011. Does omission of a regular milking event affect cow comfort? Livest. Sci. 138:132-143.

Odensten, M. O., K. Holtenius, and K. P. Waller. 2007. Effects of two different feeding strategies during dry-off on certain health aspects of dairy cows. J. Dairy Sci. 90:898-907.

Oldham, E. R., R. J. Eberhart, A. L. Lange, and S. L. Bruso. 1991. Changes in the bovine teat canal during the nonlactating period and early lactation, as measured by teat canal impressions. Am. J. Vet. Res. 52:2075-2079.

Oliver, S., and B. Mitchell. 1983. Susceptibility of bovine mammary gland to infections during the dry period. J. Dairy Sci. 66:11621166.

Oliver, S. P., T. M. Lewis, M. J. Lewis, H. H. Dowlen, and J. L. Maki. 1990. Persistence of antibiotics in bovine mammary secretions following intramammary infusion at cessation of milking. Prev. Vet. Med. 9:301-311.

Oliver, S. P., and L. M. Sordillo. 1989. Approaches to the manipulation of mammary involution. J. Dairy Sci. 72:1647-1664.

Ollier, S., X. Zhao, and P. Lacasse. 2014. Effects of feed restriction and prolactin-release inhibition at drying off on metabolism and mammary gland involution in cows. J. Dairy Sci. 97:4942-4954. 
Olori, V. E., S. Brotherstone, W. G. Hill, and B. J. McGuirk. 1997. Effect of gestation stage on milk yield and composition in Holstein Friesian dairy cattle. Livest. Prod. Sci. 52:167-176.

Oltenacu, P. A., and B. Algers. 2005. Selection for increased production and the welfare of dairy cows: Are new breeding goals needed? Ambio 34:311-315.

Österman, S., and J. Bertilsson. 2003. Extended calving interval in combination with milking two or three times per day: Effects on milk production and milk composition. Livest. Prod. Sci. 82:139149

Österman, S., K. Östensson, K. Svennersten-Sjaunja, and J. Bertilsson. 2005. How does extended lactation in combination with different milking frequencies affect somatic cell counts in dairy cows? Livest. Prod. Sci. 96:225-232.

Österman, S., and I. Redbo. 2001. Effects of milking frequency on lying down and getting up behaviour in dairy cows. Appl. Anim. Behav. Sci. 70:167-176.

Paape, M. J., B. Poutrel, A. Contreras, J. C. Marco, and A. V. Capuco. 2001. Milk somatic cells and lactation in small ruminants. J. Dairy Sci. 84:E237-E244.

Paape, M. J., and H. A. Tucker. 1969. Influence of length of dry period on subsequent lactation in the rat. J. Dairy Sci. 52:518-522.

Paape, M. J., G. R. Wiggans, D. D. Bannerman, D. L. Thomas, A. H. Sanders, A. Contreras, P. Moroni, and R. H. Miller. 2007. Monitoring goat and sheep milk somatic cell counts. Small Rumin. Res. 68:114-125.

Peaker, M. 1980. The effect of raised intramammary pressure on mammary function in the goat in relation to the cessation of lactation. J. Physiol. 301:415-428.

Persson, Y., T. Larsen, and A.-K. Nyman. 2014. Variation in udder health indicators at different stages of lactation in goats with no udder infection. Small Rumin. Res. 116:51-56.

Petridis, I. G., V. S. Mavrogianni, I. A. Fragkou, D. A. Gougoulis, A Tzora, K. Fotou, I. Skoufos, G. S. Amiridis, C. Brozos, and G. C. Fthenakis. 2013. Effects of drying-off procedure of ewes' udder in subsequent mammary infection and development of mastitis. Small Rumin. Res. 110:128-132.

Petrovski, K. R., M. Trajcev, and G. Buneski. 2006. A review of the factors affecting the costs of bovine mastitis. J. S. Afr. Vet. Assoc. $77: 52-60$.

Pezeshki, A., J. Mehrzad, G. R. Ghorbani, H. R. Rahmani, R. J Collier, and C. Burvenich. 2007. Effects of short dry periods on performance and metabolic status in Holstein dairy cows. J. Dairy Sci. 90:5531-5541

Pinedo, P. J., C. Fleming, and C. A. Risco. 2012. Events occurring during the previous lactation, the dry period, and peripartum as risk factors for early lactation mastitis in cows receiving 2 different intramammary dry cow therapies. J. Dairy Sci. 95:7015-7026.

Plommet, M., and G. Bézard. 1974. Immunisation anti-staphylococcique de la brebis par anatoxines et adjuvants. Ann. Rech. Vet. 5:29-39.

Polikarpus, A., F. Napolitano, F. Grasso, R. Di, F. Zicarelli, D. Arney, and G. De Rosa. 2014. Effect of pre-partum habituation to milking routine on behaviour and lactation performance of buffalo heifers. Appl. Anim. Behav. Sci. 161:1-6.

Pollott, G. E., and E. Gootwine. 2000. Appropriate mathematical models of describing the complete lactation of dairy sheep. Anim. Sci. 71:197-207.

Pollott, G. E., and E. Gootwine. 2004. Reproductive performance and milk production of Assaf sheep in an intensive management system. J. Dairy Sci. 87:3690-3703.

Poutrel, B., R. De Crémoux, M. Ducelliez, and D. Verneau. 1997. Control of intramammary infections in goats: Impact on somatic cell counts. J. Anim. Sci. 75:566-570.

Price, E. O., J. E. Harris, R. E. Borgwardt, M. L. Sween, and J. M. Connor. 2003. Fenceline contact of beef calves with their dams at weaning reduces the negative effects of separation on behavior and growth rate. J. Anim. Sci. 81:116-121.

Pryce, J. E., M. D. Royal, P. C. Garnsworthy, and I. L. Mao. 2004 Fertility in the high-producing dairy cow. Livest. Sci. 86:125-135.
Rabiee, A. R., and I. J. Lean. 2013. The effect of internal teat sealant products (Teatseal and Orbeseal) on intramammary infection, clinical mastitis, and somatic cell counts in lactating dairy cows: A meta-analysis. J. Dairy Sci. 96:6915-6931.

Rajala-Schultz, P. J., J. S. Hogan, and K. L. Smith. 2005. Short communication: Association between milk yield at dry-off and probability of intramammary infections at calving. J. Dairy Sci. $88: 577-579$.

Ramsay, D. T., J. C. Kent, R. A. Hartmann, and P. E. Hartmann 2005. Anatomy of the lactating human breast redefined with ultrasound imaging. J. Anat. 206:525-534.

Rastani, R. R., R. R. Grummer, S. J. Bertics, A. Gümen, M. C. Wiltbank, D. G. Mashek, and M. C. Schwab. 2005. Reducing dry period length to simplify feeding transition cows: Milk production, energy balance, and metabolic profiles. J. Dairy Sci. 88:1004-1014

Ratnayake, D. R., B. Berglund, J. Bertilsson, M. Forsberg, and H. Gustafsson. 1998. Fertility in dairy cows managed for calving intervals of 12,15 or 18 months. Acta Vet. Scand. 39:215-228.

Raynalljutovac, K., A. Pirisi, R. Decremoux, C. Gonzalo, K. RaynalLjutovac, and R. de Crémoux. 2007. Somatic cells of goat and sheep milk: Analytical, sanitary, productive and technological aspects. Small Rumin. Res. 68:126-144.

Reinhardt, C., A. Reinhardt, and V. Reinhardt. 1986. Social behaviour and reproductive performance in semi-wild Scottish Highland cattle. Appl. Anim. Behav. Sci. 15:125-136.

Ruberte, J., A. Carretero, M. Fernandez, M. Navarro, G. Caja, F. Kirchner, and X. Such. 1994. Ultra sound mammography in the lactating ewe and its correspondence to anatomical section. Small Rumin. Res. 15:199-204.

Ruiz, R., L. M. Oregui, and M. Herrero. 2000. Comparison of models for describing the lactation curve of Latxa sheep and an analysis of factors affecting milk yield. J. Dairy Sci. 83:2709-2719.

Safayi, S., P. K. Theil, L. Hou, M. Engbaek, J. V. Nørgaard, K. Sejrsen, and M. O. Nielsen. 2010. Continuous lactation effects on mammary remodeling during late gestation and lactation in dairy goats. J. Dairy Sci. 93:203-217.

Salama, A. A. K., G. Caja, X. Such, R. Casals, and E. Albanell. 2005. Effect of pregnancy and extended lactation on milk production in dairy goats milked once daily. J. Dairy Sci. 88:3894-3904.

Salama, A. A. K., G. Caja, X. Such, S. Peris, A. Sorensen, and C. H. Knight. 2004. Changes in cisternal udder compartment induced by milking interval in dairy goats milked once or twice daily. J. Dairy Sci. 87:1181-1187.

Sanchez, A., A. Contreras, and J. C. Corrales. 1999. Parity as a risk factor for caprine subclinical intramammary infection. Small Rumin. Res. 31:197-201.

Sanford, C. J., G. P. Keefe, J. Sanchez, R. T. Dingwell, H. W. Barkema, K. E. Leslie, and I. R. Dohoo. 2006. Test characteristics from latent-class models of the California Mastitis Test. Prev. Vet. Med. 77:96-108.

Santschi, D. E., D. M. Lefebvre, R. I. Cue, C. L. Girard, and D. Pellerin. 2011a. Complete-lactation milk and component yields following a short (35-d) or a conventional (60-d) dry period management strategy in commercial Holstein herds. J. Dairy Sci. 94:2302-2311.

Santschi, D. E., D. M. Lefebvre, R. I. Cue, C. L. Girard, and D. Pellerin. 2011b. Economic effect of short (35-d) compared with conventional (60-d) dry period management in commercial Canadian Holstein herds. J. Dairy Sci. 94:4734-4743.

Scherpenzeel, C. G. M., I. E. M. den Uijl, G. van Schaik, R. G. M Olde Riekerink, J. M. Keurentjes, and T. J. G. M. Lam. 2014 Evaluation of the use of dry cow antibiotics in low somatic cell count cows. J. Dairy Sci. 97:3606-3614.

Schütz, K. D. Davison, and L. Matthews. 2006. Do different levels of moderate feed deprivation in dairy cows affect feeding motivation? Appl. Anim. Behav. Sci. 101:253-263.

Silanikove, N. 2014. Natural and abrupt involution of the mammary gland affects differently the metabolic and health consequences of weaning. Life Sci. 102:10-15.

Silanikove, N., U. Merin, F. Shapiro, and G. Leitner. 2013. Early mammary gland metabolic and immune responses during natural-like 
and forceful drying-off in high-yielding dairy cows. J. Dairy Sci. 96:6400-6411.

Søndergaard, E., M. Bak, and C. J. Nicol. 2011. Motivation for social contact in horses measured by operant conditioning. Appl. Anim. Behav. Sci. 132:131-137.

Sordillo, L. M., and S. C. Nickerson. 1988. Morphometric changes in the bovine mammary gland during involution and lactogenesis. Am. J. Vet. Res. 49:1112-1120.

Sordillo, L. M., S. P. Oliver, and S. C. Nickerson. 1984. Caprine mammary differentiation and initiation of lactation following prepartum colchicine infusion. Int. J. Biochem. 16:1265-1272.

Sordillo, L. M., K. Shafer-Weaver, and D. DeRosa. 1997. Immunobiology of the mammary gland. J. Dairy Sci. 80:1851-1865.

Spanu, C., Y. M. Berger, D. L. Thomas, and P. L. Ruegg. 2011. Impact of intramammary antimicrobial dry treatment and teat sanitation on somatic cell count and intramammary infection in dairy ewes. Small Rumin. Res. 97:139-145.

Stanton, T. L., L. R. Jones, R. W. Everett, and S. D. Kachman. 1992. Estimating milk, fat, and protein lactation curves with a test day model. J. Dairy Sci. 75:1691-1700.

Steeneveld, W., Y. H. Schukken, A. T. M. van Knegsel, and H. Hogeveen. 2013. Effect of different dry period lengths on milk production and somatic cell count in subsequent lactations in commercial Dutch dairy herds. J. Dairy Sci. 96:2988-3001.

Stefanon, B., M. Colitti, G. Gabai, C. H. Knight, and C. J. Wilde 2002. Mammary apoptosis and lactation persistency in dairy animals. J. Dairy Res. 69:37-52.

Stefanowska, J., M. Plavsic, A. Ipema, and M. Hendriks. 2000. The effect of omitted milking on the behaviour of cows in the context of cluster attachment failure during automatic milking. Appl. Anim. Behav. Sci. 67:277-291.

Tatarczuch, L., C. Philip, and C. S. Lee. 1997. Involution of the sheep mammary gland. J. Anat. 190:405-416.

Tenhagen, B. A., C. Vogel, M. Drillich, G. Thiele, and W. Heuwieser. 2003. Influence of stage of lactation and milk production on conception rates after timed artificial insemination following Ovsynch. Theriogenology 60:1527-1537.

Tucker, C. B., D. E. Dalley, J.-L. K. Burke, and D. A. Clark. 2007. Milking cows once daily influences behavior and udder firmness at peak and mid lactation. J. Dairy Sci. 90:1692-1703.

Tucker, C. B., S. J. Lacy-Hulbert, and J. R. Webster. 2009. Effect of milking frequency and feeding level before and after dry off on dairy cattle behavior and udder characteristics. J. Dairy Sci. 92:3194-3203.
USDA. 2012. National statistics for milk production. Accessed October 21, 2014. http://quickstats.nass.usda.gov/.

Valizaheh, R., D. M. Veira, and M. A. G. von Keyserlingk. 2008. Behavioural responses by dairy cows provided two hays of contrasting quality at dry-off. Appl. Anim. Behav. Sci. 109:190-200.

van Knegsel, A. T. M., S. G. A. van der Drift, J. Čermáková, and B. Kemp. 2013. Effects of shortening the dry period of dairy cows on milk production, energy balance, health, and fertility: A systematic review. Vet. J. 198:707-713.

Van Saun, R. J. 2000. Pregnancy toxemia in a flock of sheep. J. Am. Vet. Med. Assoc. 217:1536-1539.

Veldhorst, M., A. Smeets, S. Soenen, R. Hursel, K. Diepvens, and M. Lejeune. 2008. Protein-induced satiety: Effects and mechanisms of different proteins. Physiol. Behav. 94:300-307.

Ventura, B. A., M. A. G. von Keyserlingk, C. A. Schuppli, and D. M. Weary. 2013. Views on contentious practices in dairy farming: The case of early cow-calf separation. J. Dairy Sci. 96:6105-6116.

Vitale, A. F., M. Tenucci, M. Papini, and S. Lovari. 1986. Social behaviour of the calves of semi-wild Maremma cattle, Bos primigenius taurus. Appl. Anim. Behav. Sci. 16:217-231.

von Keyserlingk, M. A. G., J. Rushen, A. M. de Passillé, and D. M. Weary. 2009. Invited review: The welfare of dairy cattle - Key concepts and the role of science. J. Dairy Sci. 92:4101-4111.

Walsh, J. 1974. Milk secretion in machine-milked and suckled cows. Ir. J. Agric. Food Res. 13:77-89.

Watson, D. J., and J. F. Buswell. 1984. Modern aspects of sheep mastitis. Br. Vet. J. 140:529-534.

Watts, J. M., and J. M. Stookey. 2000. Vocal behaviour in cattle: The animal's commentary on its biological processes and welfare. Appl. Anim. Behav. Sci. 67:15-33.

Wilde, C., L. Quarrie, E. Tonner, D. Flint, and M. Peaker. 1997. Mammary apoptosis. Livest. Prod. Sci. 50:29-37.

Wilde, C. J., C. H. Knight, and D. J. Flint. 1999. Control of milk secretion and apoptosis during mammary involution. J. Mammary Gland Biol. Neoplasia 4:129-136.

Wilton, J. W., E. B. Burnside, and J. C. Rennie. 1967. The effects of days dry and days open on the milk and butterfat production of Holstein Friesian cattle. Can. J. Anim. Sci. 47:85-90.

Zobel, G., K. Leslie, D. M. Weary, and M. A. G. von Keyserlingk. 2013 Gradual cessation of milking reduces milk leakage and motivation to be milked in dairy cows at dry-off. J. Dairy Sci. 96:5064-5071.

Zobel, G., K. Leslie, D. M. Weary, and M. A. G. von Keyserlingk. 2015. Ketonemia in dairy goats: Effect of dry period length and effect on lying behavior. J. Dairy Sci. 98:6128-6138. 